\title{
Education to practice to ecology: A review and preliminary evaluation of a new architectural design curriculum using computational design tools and bamboo in Haiti
}

\author{
John Osmond Naylor \\ University of Newcastle upon Tyne | UK | j.naylor73@newcastle.ac.uk \\ Nancy Leconte \\ Haiti | mfnancy.leconte@gmail.com \\ Franck Reginald Michel Vendryes \\ Bambutek | Haiti | fvendryes@gmail.com
}

\begin{abstract}
There is an absence of lightweight, sustainable construction materials in contemporary Haitian construction, a fact highlighted in the disproportionate loss of life in the 2010 Port-au-Prince earthquake. Between 2014 and 2017 the authors delivered a series of architectural design workshops in Haiti to raise awareness and develop design skills for bamboo using computational design tools. This paper provides a review of these workshops and a preliminary evaluation from surveys conducted with the course participants. Results showed architectural education had changed perceptions of bamboo and showed potential positive ecological impact due to subsequent reforestation activities instigated by participants. Weaknesses were in the lack of subsequent use of parametric modelling software. Bamboo material knowledge and a new architectural design methodology have been most relevant to their professional or academic work.
\end{abstract}

Keywords: Haiti; full-culm bamboo; architectural education; sustainable development, parametric design.

\section{INTRODUCTION}

In 2010, an earthquake hit Port-au-Prince, Haiti's capital, which caused the deaths of at least 160,000 people and tragically affected many millions more (Kolbe et al., 2010). A lack of lightweight building materials, and lack of enforcement of standards and codes played a significant role in this disproportionate death toll (Haas, 2010). Haiti also suffers chronic deforestation (Dubois, 2016), the results of which are barren hillsides that cause regular flooding and a rural exodus to the capital which increases the proportion of the population living in dense inadequate non-earthquake-resistant housing. This situation is not confined to Haiti. Globally, tropical low- and middle-income countries (LMIC's) are some of the most vulnerable societies to natural disasters, and by 2050 , some $50 \%$ of the world's population will live in the tropics (State of the Tropics, 2020). The UN Sustainable Development Goal 11 (SDG11), targets by 2030 the access for all to adequate, safe and affordable housing, and suggests that the building of sustainable and resilient buildings utilising local materials should be a catalyst for development (UNHabitat, 2016a). To achieve this locally available natural renewable materials are required for construction. This challenge should be met by architects to develop new processes to work with natural renewable materials which ensure structural integrity and affordability. Tropical developing economies are large producers of bamboo (Lobovikov, Paudel, Piazza, Ren, \& Wu, 2007), a material with good tensile and compressive properties and a low carbon footprint when sourced locally (Lugt, Vogtländer, Vegte, \& Brezet, 2015). Bamboo can be worked with simple tools and can be grown locally on a village scale or even a family scale (Janssen, 1995). Bamboo can also absorb $\mathrm{CO}_{2}$ and stabilise slopes to tackle the effects of deforestation (Tardio, Mickovski, Stokes, \& Devkota, 2017). Currently in Haiti, poverty, deforestation, pollution and waste management are growing problems (US AID, 2020). Haiti has seven naturally occurring species of bamboo as many as countries such as El Salvador, and Nicaragua (Akinlabi, Anane-Fenin, \& Akwada, 2017). Bamboo is seen by some as a latent economic and ecological asset. The built environment has an opportunity to make bamboo more visible and help convince the most sceptical. Between 2014 and 2017 a series of five architectural design workshops took place in Haiti to develop skills and awareness of the lightweight, sustainable construction material of bamboo as well as teaching a new design process for bamboo involving a parametric design approach (Caetano, Santos, \& Leitão, 2020), using parametric modelling software. This paper provides a preliminary evaluation of the impact of these courses and discusses the context of Haiti's architectural education and ecological and construction sector challenges, and the objectives of these courses to build capacity in these areas. By conducting surveys with course participants, the objectives of this paper are to:

1. Identify the perceived strengths and weaknesses of the courses from the participants' perspective.

2. Understand how the courses affected participants' attitude to bamboo. 
3. Evaluate the relevance of computational architectural design tools in Haitian architectural education and the Haitian construction industry.

4. Understand how the course has affected participants' architectural design methodologies.

5. Understand how international collaborations between schools of architecture can have a meaningful impact on sustainable development.

6. Understand if these courses resulted in direct or indirect reforestation.

7. Develop a framework for a deeper evaluation of the courses in order to plan the next steps.

\section{BACKGROUND}

"Dèyè mòn, gen mòn." or "Beyond mountains, more mountains." This age old Haitian proverb has taken on a new meaning following the political, natural and economic factors which have afflicted Haiti over the past decades. However it was originally intended to describe the unique terrain of the Island nation. This terrain is severely deforested. Approximately only one third of the country has tree coverage. This deforestation amplifies the flooding and landslides caused by hurricanes and storms (Dubois, 2016). Another consequence of a lack of mature trees is that now timber is more expensive and must be imported from abroad. This is a disheartening fact for a construction industry once regional pioneers in timber frame construction, most notably in the Gingerbread architecture of the $19^{\text {th }}$ Century (Columbia University GSAPP, 2016). Early assessments of these historic timber framed buildings undertaken after the earthquake found that traditional construction techniques proved seismically resistant. This prevented many Gingerbread structures from collapsing (Columbia University GSAPP, 2016), while over half of the contemporary built stock of predominantly unreinforced masonry in Port au Prince collapsed or was damaged enough to require repairs (Desroches, Comerio, Eberhard, Mooney, \& Rix, 2011). Near the epicentre of the earthquake, in the city of Léogâne, it is estimated that $80 \%$ $90 \%$ of the buildings were critically damaged or destroyed (Desroches et al., 2011). The need for safe and lightweight buildings in Haiti is critical and this is especially true for urban areas which are home to $57.4 \%$ of Haiti's population (UN-Habitat, 2016b). These problems have dogged Haiti for decades and it is urgent that we find realistic solutions to these problems and put emphasis on local production and be innovative.

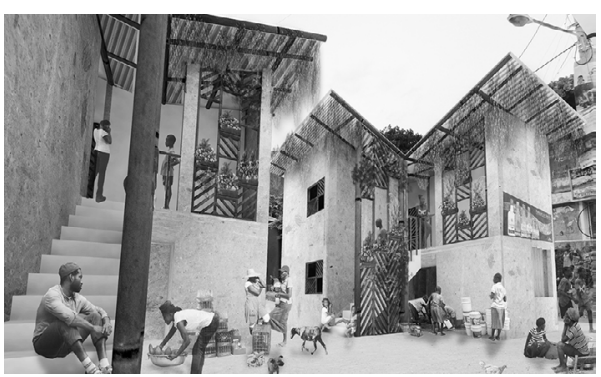

Figure 1: Student project from the Summer 2016 course and the design selected to be developed as a Bamboo Core house prototype.

How can we involve land owners, architects, entrepreneurs and crafts people into the imperative necessity of a formal bamboo network which will not only bring in substantial revenues but will stop erosion in the areas where bamboo is grown? In answering this question, the focus here is on architectural education, the process of shaping individuals to join the architecture profession, one of the most influential professions in our global society (Salleh, Md Yusoff, \& Memon, 2016). A lack of lightweight sustainable construction materials is not the result of architectural education. However current models of education are very much based in training students for the current scenario and recreating the buildings which are to be built from currently widely available materials such as concrete with steel rebar and concrete masonry units (CMU's). Client demands reinforce client perceptions of what a building is. In such an environment, the next generation of students are continuing to lose an appreciation of timber and other natural renewable materials. Haiti needs safe buildings but, for lasting change these need to be designed in Haiti by local architects, and not to "air drop solutions" (Sinclair, 2010). As Merkel and Whitaker (2010) put it, to move away from concrete towards sustainable, lightweight materials, "Haiti would need a new generation of builders adept at pounding nails rather than mixing cement." (p.133) (Merkel \& Whitaker, 2010). Architectural education has that ability and a responsibility to train the next generation of architects and engineers to be advocates for lightweight natural renewable materials. Their future professional work can incorporate these materials and step by step begin to identify local supply chains and build local capacity. With enough local demand for lightweight natural renewable materials from clients, inevitably those with barren unproductive land in Haiti will see an economic benefit from planting timbers and bamboos. Also important to note is that architects and engineers are only responsible for a minority of buildings in Port au Prince, since almost $75 \%$ of Haiti's urban population, over 4 million people, live in nonadequate housing (UN-Habitat, 2016b) which is built usually without the input of an architect or engineer. These informal buildings are often built in the image of what is considered a balance between perceived functionality, durability and cost by the home owner. If architects and engineers can be successful in promoting alternative natural materials, and demonstrating that these materials are affordable, durable and provide a functional space, over time, these few can act as a beacon to the subsequent informal buildings which are constructed. In this context in 2014, the UK based Architectural Association School of Architecture (AA) established a series of workshops to address this challenge and teach bamboo design and construction skills in Haiti, running for five courses until 2017. These courses were coordinated by the AA with support and guidance from Quisqueya University architecture department in Port au Prince, and the Wynne Farm Ecological Reserve in Kenscoff in which construction took place. They were all roughly two weeks in duration. The workshops were financed by sponsorships received from Government agencies, architecture firms and NGO's based locally in Haiti, as well as the USA, UK, and Switzerland. Fees were also paid by participants. The funding model meant overseas participants provided funding through fees which contributed to the costs of the courses. Almost $90 \%$ of the Haitian participants received scholarships for $\$ 100$ fee places or fee free places. There were 4 wider objectives established for the workshops. These were to: equip local students with computational design tools to increase the capacity to design for climatic and seismic conditions; to develop a portfolio of student 
work showcasing the aesthetic potential of bamboo buildings; to engage students, design professionals and builders in a construction course using domestically grown bamboo, demonstrating both construction techniques and existing infrastructure so skills can be disseminated; and to create a platform linking bamboo growers, land owners, and the construction industry together in Haiti while showcasing skills of those in Haiti internationally.

\section{PARTICIPANTS}

In total, over the five years there were 70 enrolments on the courses, the demographics of which are presented in Table 1 and Figure 2. Since a few Haitian enrolees were returning participants from previous courses, these 45 enrolments from Haitian participants represent 37 individual participants.

Table 1: Number of participants enrolled on each course with bars split to show the Haitian and non-Haitian enrolees. (Note: Participants who studied more than one course as an enrolee are recorded for each of their enrolments).

\begin{tabular}{llll}
\hline $\begin{array}{l}\text { Course } \\
\text { year }\end{array}$ & Haitian & $\begin{array}{l}\text { Enrolees } \\
\text { Non-Haitian }\end{array}$ & Total \\
\hline 2014 & 7 & 4 & 11 \\
2015 & 6 & 6 & 12 \\
2016 Summer & 9 & 9 & 18 \\
2016 Autumn & 7 & 5 & 12 \\
2017 & 16 & 1 & 17 \\
Total & 45 & 25 & 70 \\
\hline
\end{tabular}

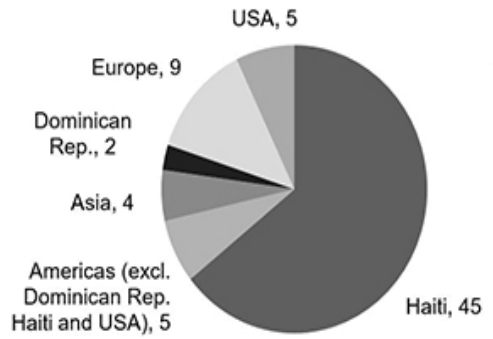

Figure 2: Number of course enrolments over the five courses broken down by geographic location. (Note: Participants who studied more than one course as an enrolee are recorded for each of their enrolments).

\section{TEACHING TEAM}

The teaching team was made up of architects from around the world. In 2014 when the course was established we had no Haitian teaching staff, only Haitian visiting lecturers. One main goal with the teaching team was that this would be an opportunity to build capacity within Haiti and over time develop a predominantly Haitian teaching team for the courses, ideally having past participants of the course return as members of the teaching team. The cooperative learning approach to active learning was employed as the means of delivering the curriculum (Keyser, 2000). Tutors acted as design coaches to drop into student groups over the course to provoke and stimulate the emerging design and offer technical support.

\section{PROGRAMME CURRICULUM}

Participants would work in groups of three and would develop one design project over the course of each workshop. Groups were designed to ensure they would always be a mix of Haitian and non-Haitian participants. Upon receiving the brief participants were to follow an iterative problem solving process based on one documented by Mitchell and Bevan (1992). Participants were encouraged to identify the problem in the brief from multiple stakeholder perspectives and identify the economic, social and material constraints in which they can design (Mitchell, 1992), with the bamboo material as the exception to this, though in proposing bamboo participants had to argue how this project would be a catalyst to develop a future bamboo infrastructure. Secondly, a method of design, build, test and assess was followed in order to inform design decisions in an iterative process (Mitchell, 1992). This process began with physical model making with bamboo sticks in order to conceptualise initial design responses to the brief. This was supported in parallel with site visits, and lectures on bamboo growth, selection, harvesting, processing and joinery. Following this, 3D modelling software was taught and participants would then build their physical models in Rhinoceros 3D (Robert McNeel \& Associates, 2020b). Upon identifying parameters which could be refined, these designs were scripted in Grasshopper (Robert McNeel \& Associates, 2020a) in order to efficiently produce new versions which could respond to changing parameters such as a changing site or alternative bamboo species selection. From 2016 onwards participants undertook bamboo harvesting and 1:1 scale bamboo construction which allowed participants to learn more about the buildability of their designs and then use this construction experience to develop the practicality of their design. Graphic design software was then taught to allow participants to properly document their design process and output. Throughout this whole process local and international architects and ecologists would give lectures to the participants presenting a vast palette of issues and ideas from which they could cultivate their design work. This provided the input of outside ideas from other bamboo growing regions of the world and provided networking opportunities for participants. At the end of the course the designs were presented to stakeholders, tutors and their peers in the course.

\section{COMPUTATIONAL DESIGN TOOLS}

Computational design brings simulation and analysis into the architectural design process. These tools produce new efficiencies, manage complexity, and explore new forms of aesthetic expression (Senske, 2017). One wider challenge of computational design tools and full-culm bamboo is the difficulties in accurately modelling an anisotropic material with natural variability (Naylor, 2020). In 2005, Willis and Woodward suggested it will be impossible to achieve a direct correlation between digital data and a constructed building. Some design parameters such as material flaws, grain directions and inconsistent densities will be difficult to anticipate in modelling software. However, this gap between the building and the model will continue to narrow (Willis \& Woodward, 2005). The design portfolios of the courses in Haiti contributed to the wider discourse and the narrowing of this gap. Participants were taught Rhinoceros 3D (Robert McNeel \& Associates, 2020b) which is a threedimensional computer graphics and computer-aided design software, and Grasshopper (Robert McNeel \& Associates, 2020a) which is a graphical algorithm editor integrated with Rhinoceros 3D. Grasshopper is primarily used to build generative algorithms. Such software allows us to specify relationships among parameters and instantly 
output versions or iterations of a design, based on associative rules set by the designer (Jabi, 2013). These tools and process can ultimately reduce the time in achieving optimal design solutions, and if time is money, then there is no more relevant application of such a design process than in Haiti. We do not expect students to master the software over the course, but simply be introduced to it. By applying computational design tools to a short design brief, we are not just teaching the software but allowing students to autonomously discover their relevance and application.

\section{FULL-CULM BAMBOO}

A fundamental principle within the course curriculum was the use of full-culm bamboo as opposed to engineered bamboo products (EBP's). By enfranchising non- or marginally-engineered building materials, we can ensure that the most affordable form of bamboo, 'full culm bamboo', (also named 'round bamboo') can be used (Harries, Sharma, \& Richard, 2012; Paraskeva, Pradhan, Stoura, \& Dimitrakopoulos, 2019).

\section{WIDER REQUIRED INTERVENTIONS}

It is important to note here that the emphasis on architectural education is only one aspect of a plan which needs to take place in order to bring about the restoration of Haitian ecology and the built environment. The authors of this paper believe unless measures are taken right now to stop the destruction of Haiti's meagre forest resources, there will be harsh environmental consequences in the future, and the most important factor in stimulating environmental participation would be providing opportunities to increase incomes (Dolisca, Carter, McDaniel, Shannon, \& Jolly, 2006). Non-timber forest products such as bamboo offer this opportunity. Bamboo is "Un passage obligé", in a real quest for sustainable development which will benefit present and future generations of citizens. The future of bamboo in Haiti should be part of a sustainable realistic development plan which considers the wellbeing of all citizens. Faith, discipline, collective work and determination are necessary to bring about and guarantee a long and healthy life to a bamboo endeavour in Haiti. These workshops are an important aspect of what needs to be a wider plan for bamboo.

\section{METHODOLOGY}

A self-administered online survey of 18 questions was used (Table 2). Of these 18 questions Q1, Q3, Q10 and Q11 were multiple-answer multiple choice questions and Q18 allowed students to respond with written text. All other questions were single answer multiple choice. Surveys were conducted by an online form in Haitian Creole. This was sent to only Haitian participants of the courses since the goal of this preliminary evaluation is to determine the subsequent local impact. Surveys asked gender, age and which course was attended, however there was no further information asked which could be used to identify the participants. With the lack of further personal information the results were anonymous. There are four key sections to the assessment. These are: attitudes for construction use of bamboo and in the wider context of Haiti; bamboo planting and reforestation activities; software, and networking. Surveys are a relatively straightforward approach to studying attitudes and values, and provide a high degree of data standardisation. Online selfadministered surveys such as the one used allow anonymity which can help to encourage frankness and honesty (Robson, 2002).

Table 2: Structure of online self-administered questionnaire. The final survey was translated and answered in Haitian Creole.

\begin{tabular}{|c|c|}
\hline Number & Question \\
\hline $\begin{array}{ll}\text { Q1 } \\
\text { Q2 }\end{array}$ & $\begin{array}{l}\text { What aspects of the course did you most enjoy? } \\
\text { Do you think such a course should be offered at a } \\
\text { University in Haiti? }\end{array}$ \\
\hline Q3 & $\begin{array}{l}\text { What aspects of the course have been the most } \\
\text { useful for your professional work or academic } \\
\text { studies after the course? }\end{array}$ \\
\hline Q4 & $\begin{array}{l}\text { Has the course changed your approach to design? } \\
\text { If so, in which way? }\end{array}$ \\
\hline Q5 & $\begin{array}{l}\text { Can you see bamboo playing an important role in } \\
\text { the future construction industry in Haiti? }\end{array}$ \\
\hline Q6 & $\begin{array}{l}\text { Before the course, had you visited anywhere in } \\
\text { which bamboo grows in Haiti? }\end{array}$ \\
\hline Q7 & $\begin{array}{l}\text { After the course, had you visited anywhere in which } \\
\text { bamboo grows in Haiti? }\end{array}$ \\
\hline Q8 & $\begin{array}{l}\text { Have you yourself planted bamboo, or been part of } \\
\text { any team which has planted bamboo, following the } \\
\text { course? }\end{array}$ \\
\hline Q9 & $\begin{array}{l}\text { If you have not participated in planting bamboo, } \\
\text { why? }\end{array}$ \\
\hline Q10 & $\begin{array}{l}\text { Before the course, where did you consider bamboo } \\
\text { suitable in construction? }\end{array}$ \\
\hline Q11 & $\begin{array}{l}\text { After the course, where do you consider bamboo } \\
\text { suitable in construction? }\end{array}$ \\
\hline Q12 & $\begin{array}{l}\text { Have you used RHINOCEROS 3D, following the } \\
\text { course? }\end{array}$ \\
\hline Q13 & $\begin{array}{l}\text { Have you used GRASSHOPPER, following the } \\
\text { course? }\end{array}$ \\
\hline $\begin{array}{l}\text { Q14 } \\
\text { Q15 }\end{array}$ & $\begin{array}{l}\text { If not, what were the reason for not using software? } \\
\text { Have you used any of the following software you } \\
\text { were taught following the course? }\end{array}$ \\
\hline Q16 & $\begin{array}{l}\text { Did this course provide an opportunity to meet new } \\
\text { people which would not normally be available to } \\
\text { you? }\end{array}$ \\
\hline Q17 & $\begin{array}{l}\text { Would you do the course again? If so, which format } \\
\text { would be best? }\end{array}$ \\
\hline Q18 & $\begin{array}{l}\text { If you could improve the course, what would you } \\
\text { change? }\end{array}$ \\
\hline
\end{tabular}

Surveys are also advantageous in their transparency in which the methods, procedures and implementation can be assessed by others (Hakim, 2000). There are internal and external validity problems with surveys. Internal being the questions themselves are incomprehensible or ambiguous resulting in a problem of obtaining the right information, and external being problems with the sampling and securing the involvement of respondents (Robson, 2002). This is particularly true with self-administered surveys which typically have a low response rate and given the anonymity, it is difficult to know how representative the responses are, and any ambiguous questions or misunderstandings by respondents are difficult to detect (Robson, 2002). Similar surveys have been used within the construction industry. In a survey of architects' awareness of sustainability in China, Bing and Yi (2015) noted the non-response bias which could affect the results, in that those who have little interest in this issue may not have replied (Bing \& Yi, 2015). Here all respondents were contacted individually. Surveys were also used in a four-year impact study to assess teaching methods for a computational thinking course (Senske, 2017). This methodology of pre- and post- class surveys was successful in that it revealed improved perception of computing and an increased interest in the subject, 
validating the premise of the course (Senske, 2017). All respondents to our survey had participated in the courses so they had already shown an interest in the wider subject matters being evaluated. It is hoped this reduces the issues with external validity. We also included an initial set of questions before the main survey to understand how the views reflected a broad range of the courses. Respondents were able to state which year they had undertaken the course. In the event a participant had taken the course on more than one occasion they would select each year they had taken the course. We were able to ensure that responses to the survey reflected views over all five courses. As shown in Table 4, the age group of respondents was also recorded with an initial survey question. The majority of those who participated in the course were current students of architecture in Port au Prince, and this younger age group was also reflected in the respondents to the survey.

Table 3: The gender representation of respondents.

\begin{tabular}{lll}
\hline Gender & No. & $\%$ \\
\hline Male & 11 & $73.3 \%$ \\
Female & 4 & $26.7 \%$ \\
Total & 15 & $100 \%$ \\
\hline
\end{tabular}

Table 4: The age demographic of survey respondents .

\begin{tabular}{lll}
\hline Age group & No. & $\%$ \\
\hline $18-24$ & 4 & $26.7 \%$ \\
$25-32$ & 9 & $60 \%$ \\
$33-40$ & 2 & $13.3 \%$ \\
$41+$ & 0 & $0 \%$ \\
Total & 15 & $100 \%$
\end{tabular}

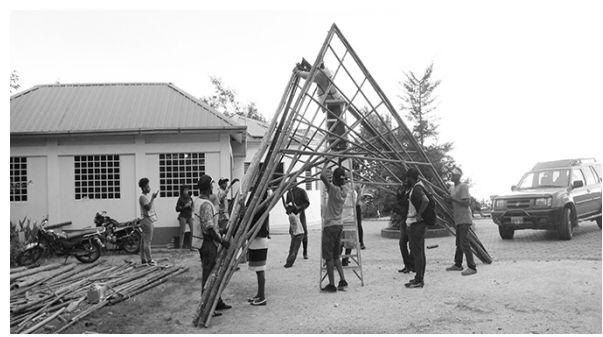

Figure 3: Construction of a small structure with locally sourced bamboo on the 2017 course.

\section{RESULTS \\ GENERAL OBSERVATIONS}

Q1 and Q3 allowed multiple answers. As shown in Figure 4 respondents noted in Q1 that bamboo material knowledge, networking, the architectural design process, and 3D modelling software had been their most enjoyable parts of the course. The bamboo material knowledge and architectural design process also scored highest when asked what had been the most useful to their subsequent professional work or academic studies (Q3). The least relevant aspect of the course from Q3, was the experience of visiting other parts of Haiti with only $7 \%$.

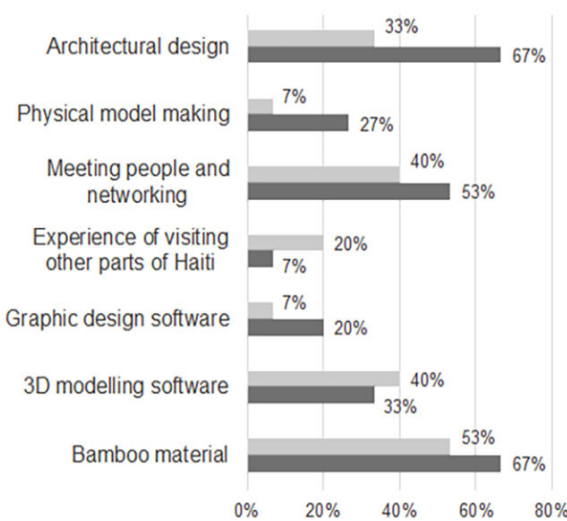

(Q1) What aspects of the course did you most enjoy?

(Q3) What aspects of the course have been the most useful for your professional work or academic studies after the course?

Figure 4: Respondents views on which aspects of the course they most enjoyed (Q1) and which aspects of the course they considered to be most useful to their professional or academic work after the course (Q3).

\section{ATTITUDE TO BAMBOO IN CONSTRUCTION}

All respondents responded positively to the question of whether they could see bamboo playing an important role in the future construction industry in Haiti (Q5). Q10 and Q11 allowed multiple answers. The responses are shown in Table 5 . Before the course only $27 \%$ of respondents thought bamboo could be used for the primary structure whereas this number increased to $93 \%$ following the course. Those who think bamboo could be used as a roof more than doubled from $40 \%$ before the course to $87 \%$ after the course. Those thinking bamboo could be used in the façade also substantially increased from $47 \%$ to $73 \%$. In fact in all building applications, more respondents were positive for bamboos application following the course. $20 \%$ of respondents noted that bamboo was not suitable for construction. This may seem unusual since at the same time $93 \%$ think it can be used in a primary structure and $87 \%$ think it can be used in a roof. However this may not necessarily be contradictory to the $93 \%$ figure as this could be for other reasons such as cultural or economic. One could think bamboo can work in a structure but also think that it is not suitable to use. This is something to investigate in future evaluation exercises.

Table 5: Respondents' attitudes to the applications of bamboo before (Q10) and after (Q11) the course. (No. of responses and percentage of respondents).

\begin{tabular}{lll}
\hline Response & Before the course & After the course \\
\hline Primary structure & $4(27 \%)$ & $14(93 \%)$ \\
Roof & $6(40 \%)$ & $13(87 \%)$ \\
Façade & $7(47 \%)$ & $11(73 \%)$ \\
Interior finishes & $9(60 \%)$ & $12(80 \%)$ \\
Furniture & $13(87 \%)$ & $15(100 \%)$ \\
Not suitable & $0(0 \%)$ & $3(20 \%)$ \\
for construction & & \\
No opinion & $1(7 \%)$ & $0(0 \%)$ \\
\hline
\end{tabular}




\section{DESIGN METHODOLOGY}

Table 6: Responses to Q4. Has the course changed your approach to design? If so, in which way?

\begin{tabular}{lll}
\hline Response & No. & $(\%)$ \\
\hline No & 1 & $6.7 \%$ \\
Use of materials & 2 & $13.3 \%$ \\
Conception of form & 7 & $46.6 \%$ \\
The role of design in a social context & 4 & $26.7 \%$ \\
Other & 1 & $6.7 \%$ \\
Total & 15 & $100 \%$ \\
\hline
\end{tabular}

As shown above in Table 6 , all but 1 of the respondents stated the course had in some way changed their approach to design with the role of design in a social context and the conception of form as the highest.

\section{BAMBOO PLANTING}

As shown in Table 7, the course had a positive impact on exposing participants to bamboo as a plant and linking participants to reforestation exercises. $20 \%$ of respondents had said they had subsequently been part of a team which had planted bamboo in Haiti. For those who answered 'no', Q9 was an opportunity to state the reasons for not planting bamboo. The results from 11 responses, as shown in Table 8 , were mixed with most respondents recording reasons which were not listed.

Table 7: Responses to Q6, Q7 and Q8.

\begin{tabular}{lcr}
\hline Response & Yes $(\%)$ & No $(\%)$ \\
\hline Have you visited anywhere in which bamboo grows in Haiti? \\
Q6. Before the course & $7(46.7 \%)$ & $8(53.3 \%)$ \\
Q7. After the course & $13(86.7 \%)$ & $2(13.3 \%)$
\end{tabular}

Q8. Have you yourself planted bamboo, or been part of any team which has planted bamboo, following the course? $3(20 \%)$ $12(80 \%)$

In response to Q9, other reasons for participants not planting bamboo ranged from not finding time to pursue this to not being based anymore in Haiti. However 5 of the 8 other responses such as, "Did not get opportunities," or, "Because I did not find organizations, groups, teams to participate in these activities," could also be categorised as a lack of opportunity. Since no respondents responded with a lack of interest or the feeling that planting bamboo does not make sense, it can be safely deduced that there is a desire of the participants to plant bamboo, but a lack of opportunity stands in the way.

Table 8: Responses to Q9.

\begin{tabular}{lcc}
\hline Response & $\begin{array}{c}\text { Number of } \\
\text { Responses }\end{array}$ & $\begin{array}{c}\% \text { of responses } \\
\text { to Q9 }\end{array}$ \\
\hline $\begin{array}{l}\text { If you have not participated in planting bamboo, } \\
\text { Lack of funding }\end{array}$ & 1 & $9.1 \%$ \\
No interest in planting & & $0 \%$ \\
bamboo & 0 & \\
Feel it does not make & & $0 \%$ \\
sense to plant \\
bamboo in Haiti \\
$\begin{array}{l}\text { Lack of market for } \\
\text { bamboo }\end{array}$ \\
$\begin{array}{l}\text { Lack of opportunity } \\
\text { to participate }\end{array}$
\end{tabular}

\section{SOFTWARE}

Participants were asked if they have used Rhinoceros 3D or Grasshopper following the course, and in which capacity (Table 9).

Table 9: Respondents' answers to subsequent use and application of Rhinoceros 3D (Q12), and Grasshopper (Q13) softwares taught on the course.

\begin{tabular}{llc}
\hline Response & $\begin{array}{l}\text { No. } \\
\text { of responses }\end{array}$ & $\begin{array}{c}\% \text { of } \\
\text { responses }\end{array}$ \\
\hline Q.12. Have you used Rhinoceros 3D, following the course? \\
Yes, in a university project & 0 & $0 \%$ \\
Yes, in professional work & 2 & $13.3 \%$ \\
Yes, in personal projects & 6 & $40 \%$ \\
No, not used & 5 & $33.3 \%$ \\
Other & 2 & $13.3 \%$ \\
Total & 15 & $100 \%$ \\
Q13. Have you used Grasshopper, following the course? \\
Yes, in a university project & 0 & $0 \%$ \\
Yes, in professional work & 0 & $0 \%$ \\
Yes, in personal projects & 1 & $7.7 \%$ \\
No, not used & 11 & $84.6 \%$ \\
Other & 1 & $7.7 \%$ \\
Total & 13 & $100 \%$ \\
\hline
\end{tabular}

Responses from the 2016 Autumn course were omitted since Rhinoceros and Grasshopper were not taught on this course. The responses for subsequent use of Rhinoceros 3D showed that roughly half of respondents had used Rhinoceros 3D in their professional work and personal projects. Those who responded to 'Other' commented in ways which show that they did not continue to use Rhinoceros 3D, with one of these responses stating they would like to with further training. However, subsequent use of Grasshopper was minimal with only one positive response and two respondents not answering this question.

\section{NETWORKING}

For Q16, 93\% of respondents stated that this course provided an opportunity to meet new people which would not normally be available to them.

\section{COURSE DURATION AND FUTURE FORMATS}

Table 10: Respondents' answers to Q17, Would you do the course again? If so, which format would be best?

\begin{tabular}{lll}
\hline Response & $\begin{array}{l}\text { No. of } \\
\text { resp. }\end{array}$ & \\
\hline No & 0 & $0 \%$ \\
Yes, same length and format & 2 & $13.3 \%$ \\
Yes, same format but longer duration & 12 & $80.0 \%$ \\
Yes, a semester length course at & 1 & $6.7 \%$ \\
University & & \\
Total & 15 & $100 \%$ \\
\hline
\end{tabular}

There was unanimous agreement from respondents that this course should be offered at a university in Haiti (Q2). Table 10 shows the responses when participants were asked about future formats, most thought the course should be a longer duration. Q18 of the survey was an opportunity for respondents to provide additional comments, with no limit on the size of the text. Of these responses the vast majority reinforced the responses to Q17. Some of these comments included: "I would make the training last longer so the students would have a better 
understanding of the training and get to use the software better"; "I would increase the amount of time"; "Since the training is built over a very short duration, the time to fully understand and assimilate the software should take more time"; "Our time is spent learning software and the time is not enough to allow us to have a good foundation", and, "More time."

\section{RESPONSE RATE}

With 15 responses representing $41 \%$ of the 37 participants the response rate was lower than we would have hoped for. The results however still reveal an insight into successes and challenges and provides guidance for further evaluation. That said, a low response rate does not necessarily mean that a survey suffers from a large amount of nonresponse error (Krosnick, Lavrakas, \& Kim, 2014).

\section{DISCUSSION}

The first objective of this paper was to identify the perceived strengths and weaknesses of the courses from the participant perspective. From the responses it appears the strengths of the course were in the networking opportunities, and learning about bamboo. There was unanimous agreement that bamboo could play an important role in Haitian construction with all respondents responding positively to the question of whether the respondent could see bamboo playing an important role in the future construction industry in Haiti (Q5). The responses to Q10 and Q11 are shown in Table 5. Before the course only $27 \%$ of respondents thought bamboo could be used for the primary structure whereas this number increased to $93 \%$ following the course. $20 \%$ of respondents had said they had subsequently been part of a team which had planted bamboo in Haiti (Q8). Subsequent to the last course, one particular participant was able to harness the lessons from the workshop with real life experience, implementing a reforestation programme which has the self-stated goal of encouraging the rural and urban population to plant bamboo to allow financial independence and stem the problem of Haiti's rural exodus (Facile, 2019a). The authors have also been made aware of the scope and quantity of bamboo planted through this endeavour. This programme received funding to plant 1000 seedlings in phase 1, with 5000 seedlings in phase 2 and claiming to directly impact 10000 people (Facile, 2019b). Two thirds of respondents said that the architectural design methodology and knowledge of bamboo had been useful to their subsequent professional or academic work. Respondents all stated they would do the course again and wished it to be a longer course, unanimously wanting such a course at university (Q2). An apparent weakness from the responses appears to be in the teaching of parametric modelling software without adequate time on the course to do so. 3D modelling software was relevant to respondents (Q3), though subsequent use of Grasshopper showed this not to be relevant (Q13). This begs the question whether it would have been more impactful to not teach parametric modelling software, but focus more on the $3 \mathrm{D}$ modelling given the short timeframe we had for each of these courses.

\section{CONCLUSION}

Firstly, architectural education when linked to an ecological agenda can impact ecology and can inspire those who do the course to instigate reforestation. $20 \%$ of respondents stated they had participated in planting bamboo following the course and we are aware that one participant has implemented a reforestation programme (Facile, 2019b). Perhaps this course has influenced this, whether this was by inspiring the participants to plant bamboo or facilitating the networking which allowed the planting to occur. This should be investigated more as the story of this could have wider relevance to understand how more participants could get involved in planting bamboo and become advocates to landowners to plant bamboo. Access to funds is a key point in following up and setting up a planting programme, and without this know-how, potential interest in bamboo is nipped in the bud. Secondly, architectural education can change perceptions of lightweight sustainable materials such as bamboo. The fact that respondents both enjoyed and found useful the bamboo material information (Q1 and Q3), $100 \%$ of respondents thought bamboo had an important role to play in construction (Q5), and there were significant positive changes in the perception of bamboo from the responses to Q10 and Q11. This shows the importance of materials in architectural education, not just for Haiti. In retrospect, the survey could have further investigated bamboo advocacy, to understand how the participants introduced the material to others, from tentatively suggesting it to actively arguing for use in construction with clients. Furthermore, the survey gives no insight on how the participants' university tutors have responded to the suggestion of using bamboo. Indeed, even though this course was open to all ages those who undertook the course were predominantly of university age. As highlighted in Q4, these courses affected participants' attitudes to architectural design and how we see the role of the architect. Nearly a third of respondents noted this course had changed the role of design in a social context. Responses showed that overall the 3D modelling software was relevant, though it is inconclusive the reasons why parametric modelling software was not useful following the course. This could be a lack of knowledge resulting in a lack of use. This could be remedied by a greater length of training as the majority of respondents thought this should be done in response to Q17. It would be beneficial for this evaluation to ask if participants felt these courses had helped in finding employment following the course. However, by engaging with respondents through this study, it is very evident that even before the COVID-19 pandemic of 2020 , there was ongoing political unrest in Haiti along with slow devaluation of the currency and economic challenges for the last few years. Therefore it is a difficult time to question participants on their careers. This can be inquired with far more empathy in future personal interviews and will allow us to understand the success of the networking opportunities. These initial survey results should now be backed up by qualitative interviews. In getting this information we can build on these results and the strengths and weaknesses of the course and develop a plan for the future in order to keep the goals of this course alive. One thing is key: the founding principles of these workshops are as relevant today as they were on the first course in January 2014.

\section{ACKNOWLEDGMENTS}

Thank you to Jane Wynne, Doria Reyes Córdova, Rose Di Sarno, Aditya Aachi, Diego Perez Espitia and Dr Ben Bridgens who provided insight and expertise although interpretations, conclusions and any errors in this paper are our own. 


\section{REFERENCES}

Akinlabi, E. T., Anane-Fenin, K., \& Akwada, D. R. (2017). Bamboo Taxonomy and Distribution Across the Globe. In Bamboo: The Multipurpose Plant (pp. 1-37). Cham: Springer International Publishing.

Bing, X., \& Yi, C. (2015). Chinese Architects' Awareness of, and Attitudes towards, Low-Carbon Architectural Design. Architecture Research, 5(3), 89-96. doi:10.5923/j.arch.20150503.01

Caetano, I., Santos, L., \& Leitão, A. (2020). Computational design in architecture: Defining parametric, generative, and algorithmic design. Frontiers of Architectural Research, 9(2), 287-300. doi:10.1016/j.foar.2019.12.008

Columbia University GSAPP. (2016). The Gingerbread Houses of Port-au-Prince, Haiti(pp. 82). Retrieved from https://www.wmf.org/sites/default/files/article/pdfs/haiti-report.pdf

Desroches, R., Comerio, M., Eberhard, M., Mooney, W., \& Rix, G. (2011). Overview of the 2010 Haiti Earthquake. Earthquake Spectra, 27, S1-S21. doi:10.1193/1.3630129

Dolisca, F., Carter, D. R., McDaniel, J. M., Shannon, D. A., \& Jolly, C. M. (2006). Factors influencing farmers' participation in forestry management programs: A case study from Haiti. Forest Ecology and Management, 236(2), 324-331. doi:https://doi.org/10.1016/j.foreco.2006.09.017

Dubois, L. (2016, 17/10/2016). Who Will Speak for Haiti's Trees? New York Times. Retrieved from https://www.nytimes.com/2016/10/18/opinion/who-will-speakfor-haitis-trees.html

Facile, J. (2019a). Bamboo: A living green Future in Haiti (Bambou Facile). Retrieved from https://www.youthlead.org/resources/bamboo-living-greenfuture-haiti-bambou-facile

Facile, J. (2019b). PREBHA (Programme de Reboisement Bambou en Haiti). Retrieved from https://www.youthlead.org/innovations/prebha-programmede-reboisement-bambou-en-haiti

Haas, P. (2010). When bad engineering makes a natural disaster even worse [Video]. TED Senior Fellows at TEDGlobal 2010. Retrieved

from https://www.ted.com/talks/peter_haas_when_bad_engineerin g_makes_a_natural_disaster_even_worse

Hakim, C. (2000). Ad hoc sample surveys. In C. Hakim (Ed.), Research design : successful designs for social and economic research (2nd ed.. ed., pp. 76-94). London: Routledge.

Harries, K. A., Sharma, B., \& Richard, M. (2012). Structural Use of Full Culm Bamboo: The Path to Standardization. International Journal of Architecture, Engineering and Construction, 1(2), 66-75. doi:10.7492/ijaec.2012.008

Jabi, W. (2013). Parametric design for architecture: London : Laurence King Publishing.

Janssen, J. J. A. (1995). Building with bamboo : a handbook (2nd ed.. ed.). London: London : Intermediate Technology Publications.

Keyser, M. W. (2000). Active learning and cooperative learning: understanding the difference and using both styles effectively. Research Strategies, 17(1), 35-44. doi:https://doi.org/10.1016/S0734-3310(00)00022-7

Kolbe, A. R., Hutson, R. A., Shannon, H., Trzcinski, E., Miles, B., Levitz, N., . . Muggah, R. (2010). Mortality, crime and access to basic needs before and after the Haiti earthquake: a random survey of Port-au-Prince households. Medicine, Conflict and Survival, 26(4), 281-297. doi:10.1080/13623699.2010.535279

Krosnick, J. A., Lavrakas, P. J., \& Kim, N. (2014). Survey Research. In C. M. Judd \& H. T. Reis (Eds.), Handbook of Research Methods in Social and Personality Psychology (2 ed., pp. 404-442). Cambridge: Cambridge University Press.
Lobovikov, M., Paudel, S., Piazza, M., Ren, H., \& Wu, J. (2007) World bamboo resources - A thematic study prepared in the framework of the Global Forest Resources Assessment 2005 Retrieved from Rome: http://www.fao.org/3/a1243e/a1243e00.pdf

Lugt, P. v. d., Vogtländer, J. G., Vegte, J. H. v. d., \& Brezet, J. C (2015). Environmental Assessment of Industrial Bamboo Products - Life Cycle Assessment and Carbon Sequestration. Paper presented at the 10th World Bamboo Congress, Korea.

Merkel, J., \& Whitaker, C. (2010). Rebuilding from Below the Bottom: Haiti. Architectural Design, 80(5), 128-134. doi:10.1002/ad.1147

Mitchell, M. (1992). Culture, cash and housing : community and tradition in low-income building. London: London : VSO/IT.

Naylor, J. O. (2020). The Opportunities and Challenges of Using Parametric Architectural Design Tools to Design with FullCulm Bamboo. In M. Awang \& M. R. Meor M Fared (Eds.), Lecture Notes in Civil Engineering. ICACE 2019 (Vol. 59, pp. 9-18). doi:https://doi.org/10.1007/978-981-15-1193-6_2

Paraskeva, T., Pradhan, N. P. N., Stoura, C. D., \& Dimitrakopoulos, E. G. (2019). Monotonic loading testing and characterization of new multi-full-culm bamboo to steel connections. Construction and Building Materials, 201, 473483. doi:10.1016/j.conbuildmat.2018.12.198

Robert McNeel \& Associates. (2020a). Grasshopper 3D. Retrieved from https://www.grasshopper3d.com/

Robert McNeel \& Associates. (2020b). Rhinoceros 3D (Version 6). Retrieved from http://www.mcneel.com/

Robson, C. (2002). Real world research : a resource for social scientists and practitioner-researchers (2nd ed.. ed.). Oxford: Oxford : Blackwell Publishers.

Salleh, R., Md Yusoff, M. A., \& Memon, M. (2016). Attributes of Graduate Architects: An Industry Perspective. The Social Science Journal, 11, 551-556. doi:10.3923/sscience.2016.551.556

Senske, N. (2017). Evaluation and Impact of a Required Computational Thinking Course for Architecture Students. Paper presented at the Proceedings of the 2017 ACM SIGCSE Technical Symposium on Computer Science Education, Seattle, Washington, USA. https://doi.org/10.1145/3017680.3017750

Sinclair, C. (2010). The Role of The Architect in Rebuilding Haiti: To Compete or To Construct? Retrieved from https://www.huffpost.com/entry/the-role-of-thearchitect_b_453905

State of the Tropics. (2020). State of the Tropics 2020 Report. Retrieved from Townsville, Australia: https://www.jcu.edu.au/state-of-the-tropics/publications/2020

Tardio, G., Mickovski, S. B., Stokes, A., \& Devkota, S. (2017). Bamboo structures as a resilient erosion control measure. Proceedings of the Institution of Civil Engineers - Forensic Engineering, 170(2), 72-83. doi:10.1680/jfoen.16.00033

UN-Habitat. (2016a). SDG-Goal 11 Monitoring Framework. Retrieved from Nairobi: https://unhabitat.org/sites/default/files/download-managerfiles/SDG\%20Goal\%2011\%20Monitoring\%20Framework.pdf

UN-Habitat. (2016b). Slum Almanac 2015/2016: Tracking Improvement in the Lives of Slum Dwellers. Retrieved from Nairobi: https://unhabitat.org/sites/default/files/downloadmanager-files/Slum\%20Almanac\%202015-2016 PSUP.pdf

US AID. (2020). Haiti - Complex Emergency Fact Sheet \#2 (2). Retrieved from https://www.usaid.gov/sites/default/files/documents/1866/07. 02.20 - USADBHA_Haiti_Complex_Emergency_Fact_Sheet_2.pdf

Willis, D., \& Woodward, T. (2005). Diminishing Dificulty: Mass Customization and the Digital Production of Architecture. Harvard Design Magazine(23), 71-83. 